DOI https://doi.org/10.30525/978-9934-26-110-7-81

\title{
ОСНОВНІ ВИДИ ПРОГРАМНИХ КОМПЕТЕНТНОСТЕЙ НАВЧАЛЬНОЇ ДИСЦИПЛІНИ «ІНОЗЕМНА МОВА» (БАКАЛАВРСЬКИЙ РІВЕНЬ)
}

\author{
Малиновська О. Л. \\ кандидат філологічних наук, \\ дочент кафедри іноземних мов \\ Державний вищий навчальний заклад \\ «Національний лісотехнічний університет Украӥни» \\ Масон С. P. \\ старший викладач кафедри іноземних мов \\ Державний вищий навчальний заклад \\ «Національний лісотехнічний університет Украӥни»
}

\author{
Чаплик О. А. \\ старший викладач кафедри іноземних мов \\ Державний вищий навчальний заклад \\ «Національний лісотехнічний університет України» \\ м. Львів, Украӥна
}

Навчальна дисципліна «Іноземна мова» $є$ важливою складовою системи підготовки майбутніх спеціалістів у немовних вищих навчальних закладах, що зумовлено тенденцією до світової інтеграції, розширенням культурного та наукового обміну, росту міжнародного економічного співробітництва. Виходячи з цього, виникає потреба у підготовці таких фахівців, які б гідно посіли місце у міжнародному розподілі праці. Дана навчальна дисципліна базується на активізації, систематизації та узагальненні знань на теоретичному на фундаментальному рівнях. Метою та завданням навчальної дисципліни «Іноземна мова» є: формування необхідної комунікативної спроможності у сферах ситуативного спілкування в усній і письмовій формах, яка передбачає вміння та здатність студента: володіти відповідними комунікативними навичками у ході різних ситуацій спілкування на загальні теми, володіти композиційно-мовленнєвими формами іншомовного мовлення, чітко дотримуватись когезивно-когерентних зв'язків у потоці іншомовного мов- 
лення, доводити свою точку зору щодо проблеми, яка обговорюється (висловлювати опис, доказ, аргументацію, оцінку, заперечення тощо). Здатність орієнтуватися у різних комунікативних ситуаціях, володіючи лінгвальними та паралінгвальними засобами спілкування, формувати у собі поведінку полікультурної особистості; адаптуватися до культури країни, мова якої вивчається, адекватно сприймати наявність міжкультурних відмінностей.

Перш, ніж перейти до розгляду основних видів компетентностей для навчальної дисципліни «Іноземна мова», слід уточнити сутність понять «компетенція» і «компетентність», які доволі часто плутають, а в окремих випадках - ототожнюють. Незважаючи на те, що ці поняття, звісно, мають свої точки дотику, однак вони $є$ абсолютно різними за своєю сутністю. «Компетенція» - це свого роду вимога до освітньої підготовки якостей особистості, «компетентність» - це завжди результат на поставлену освітню вимогу. Звідси можна стверджувати, що «компетентність» - це володіння/оволодіння певною компетенцією. Іншими словами, «компетенція» виступає як категорія «знати», а «компетентність» - як категорія «вміти» (вміти використовувати відповідні знання, вміння і навички в освітньо-навчальній та професійній діяльності) [1, с. 53].

Отже, компетентність $є$ результатом набуття компетенцій і має складовий елемент готовності до ситуації, до виконання поставленої завдачі через перехід від якості знання до якості діяльності [2, с. 75].

Таким чином, у якості діяльності, як результат програмних вимог навчальної дисципліни «ноземна мова», ми виділяємо наступні види компетентностей: Лінгвістична компетентність - володіння фонетичними, артикуляційними, орфографічними, лексичними, граматичними, синтактико-стилістичними навичками. Комунікативна компетентність - володіння усним мовленням: монологічним, діалогічним, полілогічним. Соціокультурна компетентність - володіння необхідними соціокультурними знаннями про країну, мова якої вивчається та вміння використовувати їх у ході іншомовного спілкування. Вміння гідно представляти свою країну та ії культуру іноземною мовою. Компенсаторна компетентність - вміння виходити із становища в умовах дефіциту мовних та мовленнєвих засобів щодо отримання та передачі інформації. Навчально-пізнавальна компетентність - навички самостійної роботи 3 іншомовним матеріалом, в т.ч із використанням інформаційно-комунікаційних технологій (ІКТ). Мотиваційна компеmентність - здатність усвідомлювати мету і завдання навчання, вміння правильно організувати свою навчальну роботу, формування 
позитивного ставлення до навчального процесу в цілому, не зупинятись на досягнутому, здатність бачити свої успішні перспективи, як результат освітнього процесу загалом. Когнітивна компетентність - готовність до постійного підвищення навчально-освітнього рівня, бажання та здатність до реалізації особистісного потенціалу та розвитку, здатність до саморозвитку та самостійної пізнавальної діяльності. Дискурсивна компетентність - здатність продукувати іншомовну надфразову єдність - цілісні, логічні висловлювання. Здатність дотримуватись принципів когезії та когерентності у потоці іншомовного мовлення 3 метою побудови та інтерпретації зв'язного тексту. Комn'ютерна ma мультимедійна компетентність - здатність оволодівати сучасними мультимедійними знаннями, навичками та інноваційними методами навчання; навчатися за допомогою засобів мультимедіа та здатність створювати власний іншомовний мультимедійний контент. Соціальноінформаційна компетентність - володіння IКТ та здатність аналізувати інформацію у засобах масової інформації. Інтерактивна компетентність - здатність навчатися за допомогою інтерактивних методів навчання, здатність до активізації іншомовної пізнавальної діяльності за допомогою активного спілкування (робота в парах, рольові ігри, дискусія, полеміка, здатність до моделювання різних іншомовних ситуативних контекстів мовленнєвої взаємодії відповідно до комунікативного наміру та прагматичної установки відправника тексту зокрема та дидактичної мети загалом). Міжкультурна компетентність - здатність долати бар'єри і труднощі при зіткненні з чужою культурою та їі носіями, здатність проявляти толерантність до стереотипів чужої культури. Здатність адаптуватися до культури країни, мова якої вивчається, адекватно сприймати наявність міжкультурних відмінностей. Міжкультурно-інтеграційна компетентність здатність формувати у собі поведінку полікультурної особистості, здатність запозичення правил, норм поведінки, культурних цінностей на такому рівні, що сприймаються, як рідні. Науково-пізнавальна компетентність - здатність до абстрактного мислення: аналізу, синтезу, індукції, дедукції та вміння оперувати ними. Здатність використовувати у своєму мовленні різні композиційно-мовленнєві форми (КМФ): умовиводи, міркування, опис, трактування, заперечення, критику, доказ, підтвердження, оцінювання тощо. Емоційна комnemeнтність - вміння керувати своїми емоціями, вміння розпізнавати та спрогнозувати емоції свого співрозмовника, здатність до емоційного відгуку із використанням у своєму мовленні емоційно-оцінної лексики, в т.ч. меліоративної та пейоративної. Екологічна компетент- 
ність - здатність забезпечити гармонійну взаємодію 3 природним довкіллям в усіх сферах життєдіяльності; бути обізнаним з проблемами довкілля країни, мова якої вивчається. Загальнокультурна та гуманістична компетентність - адекватно сприймати духовноморальні основи життя народу, мова якого вивчається, бути обізнаним у його побутовій та культурній сферах. Формувати гуманістичний світогляд, моральні та естетичні цінності, особистісні риси громадянина України, який сприймає i поділяе національні та загальнолюдські цінності, відчуває свою приналежність до європейської спільноти.

Усі вищезгадані нами види компетентностей по суті являють собою концепцію сучасної мовної освіти в Україні, стратегічною метою якої є формування високоосвіченої, інтелігентної, самодостатньої творчої особистості з інноваційним типом мислення і діяльності, здатної гідно відповісти на виклики цивілізації [3, с. 157].

\section{Література:}

1. Ванівська О. М., Малиновська О. Л., Преснер Р. Б. Класифікація ключових програмних компетентностей як основа оволодіння іншомовною комунікацією. Педагогічні науки. Збірник наукових праць Херсонського держ. ун-ту, - Вип. LXXX, Том 3. Херсон, 2017. С. 51-56.

2. Леонтян М. А. Поняття «компетенція» і «компетентність» у теорії освіти. Наукові прачі Чорноморського державного університету імені Петра Могили комплексу «Києво-Могилянська академія». Сер.: Педагогіка. 2012. Т. 188. Вип. 176. С. 73-75.

3. Малиновська О. Л., Масон С. Р. Навчальні матеріали за професійним спрямуванням у системі викладання іноземної мови студентам лісотехнічного профілю. Науковий вісник НЛТУ Украӥни. 2018, т. 28, № 5. C. 157-159. 